\title{
2 An emerging user-led participatory methodology
}

\author{
Mapping impact pathways of urban \\ food system sustainability innovations
}

\author{
Elodie Valette, Kerstin Schreiber, \\ Damien Conaré, Veronica Bonomelli, \\ Alison Blay-Palmer, Nicolas Bricas, \\ Denis Sautier, and Olivier Lepiller
}

\section{Introduction}

Given the growing pressures on our planet by the current food system, it is increasingly important to understand the transformative potential of urban food systems and their capacity to build pathways to sustainability. According to the United Nations, more than half of the world's population now lives in urban areas with predictions that this proportion will increase to approximately two-thirds by 2050 . Given current lifestyle and consumption practices, people living in urban areas monopolize three-quarters of all natural resources and account for 60-80 per cent of global GHG emissions (UNEP, 2011; Chapter 1, this volume).

But if cities concentrate sustainability problems, they are also (like rural communities) places of innovation that can contribute to building more sustainable food systems. Both urban government and citizen food initiatives flourish in Northern and Southern cities and offer new ways of feeding cities and connecting actors of urban and rural territories around food issues (Rocha \& Lessa, 2009; Viljoen \& Wiskerke, 2012; Robineau, 2015; BlayPalmer et al., 2016; Brand et al., 2017; Blay-Palmer et al., 2018). Largely supported by civil society or local governments, these initiatives are usually presented as alternatives to the dominant food system (Lang, 1999; Moragues-Faus \& Marsden, 2017) and ways to contest agro-industrial capitalism.

However, few research activities, so far, have aimed to analyse the effect of urban-driven changes occurring across both transitioning and industrialized countries on diverse sustainability dimensions. While numerous innovative initiatives are generated by cities - either by the public sector (Friedmann, 2007; Reynolds, 2009; Mah \& Thang, 2013; Laidlaw, 2015), private sector (Brand, 2015; Reardon, 2015), or by consumers themselves (WertheimHeck et al., 2014), their actual effects on sustainability have been insufficiently documented (see Chapter 9, this volume). Moreover, while there is 
an implicit positive causal relationship between urban innovations and sustainability, most of these relationships remain undocumented and unclear.

Among them, for example, is the idea that local food trade is inherently environmentally friendly (Katz, 2010) or socially just. Yet many works show the complexity and relative truth of this assertion (Born \& Purcell, 2006; Desrochers \& Shimizu, 2008). Some of these innovations may also have negative impacts on social issues. Slocum et al. (2016) pointed out how, in spite of the will to create and inhabit more equitable food spaces, the food movement often fails to lead to food justice, instead reinforcing existing race, class, and gender inequalities (Clancy, 1994; Freidberg, 2003). In a nutshell, urban food innovations do not necessarily address sustainability issues.

Additionally, existing initiatives that focus on indicators, such as the UN Sustainable Development Goals, privilege technocratic approaches and data, while case-study analyses can be limiting in terms of their transferability (see Chapters $1 \& 12$, this volume). Within this context, understanding how to move towards increasingly sustainable city region food systems is a challenge. The research programme URBAL (Urban-driven Innovations for Sustainable Food Systems) (2018-2020), funded by Agropolis Fondation (France), Fondation Daniel \& Nina Carasso (France/Spain), and Fundazione Cariplo (Italy), and coordinated by CIRAD (France) and the Laurier Center for Sustainable Food Systems at Wilfrid Laurier University (Canada), seeks to build and test a participatory methodology to identify and map the impact pathways of urban-driven innovations on all the dimensions of food systems sustainability. By testing this methodology through various case studies internationally - Urban Food Innovation Labs (UFILs), including sites in the Global South and North - this project aims to provide decision makers with information on how innovations can contribute to, or work against, building more sustainable food systems, thus assisting them to determine which actions should or should not be taken (see Chapters $3 \&$ 9 , this volume).

This chapter presents the general framework for the URBAL project as well as the main interwoven considerations and approaches that are the backbone of the methodology. Please note that this is an ongoing project and that it has evolved since the chapter has been written. We will point out some changes in the methodology as the chapter proceeds.

\section{How to assess the impact of urban-driven innovations on the sustainability of food systems?}

The main objective of the URBAL project is to provide urban policymakers, urban innovators, and funders with a low-cost, easy-to-implement, and context-adaptable methodology that can be used as a robust tool to make the impact pathways of innovations on all the dimensions of the sustainability of food systems more explicit. Its purpose is not to provide evaluation per 
se, but rather to help uncover the ways social innovations link with sustainability. Hence URBAL builds from existing work on different topics: impact pathway mapping, innovation with an emphasis on social innovation, participatory action research, and sustainable food system assessment.

In the field of food system assessment, numerous implementation projects and research efforts have aimed at identifying relevant indicators to assess food system sustainability. These range in number from a few to more than one hundred indicators that strive to address all the dimensions of sustainability (Singh et al., 2012). For example, FAO and RUAF Foundation (Holland), associated with the Center for Sustainable Food Systems at Wilfrid Laurier University (Canada), developed a set of indicators to map and assess city region food system sustainability (see Chapter 9, this volume). This tool has been tested on several city regions in the world. The Milan Urban Food Policy Pact has also developed a set of indicators to measure urban food system sustainability.

These are nevertheless time- and money-intensive methodologies that cannot be used easily by local authorities or innovators to better inform their decisions and actions in a context where budgets are limited. This leads many policymakers to plan without a clear idea of the impact they can expect (Jobert \& Muller, 1987; Callon et al., 2001). For these reasons, it is necessary to explore simpler and participatory methodologies that can foster social learning in the context of public policy (Bennett \& Howlett, 1992; Hall, 1993; Rose, 1993).

\section{Mainly quantitative evaluation methodologies}

Reliable analysis and evaluation techniques (Patton, 2012), including 'utilization-focused evaluation', are applied widely. Yet, work on the link between food systems and holistic sustainability is scarce (Aubin et al., 2013) and almost non-existent in relation to social innovations and impact pathways. That said, there has been some progress. Popov et al. (2017) have analysed social innovation using a quantitative approach to measure impacts of social innovation. Dhondt et al. (2016) developed a socio-economic impact analysis. Wiek et al. (2017) use log modelling to analyse sustainability experiments in cities, forming the foundation for the evaluation scheme of Luederitz et al. (2017), who integrate sustainability transitions. Luederitz et al. looked specifically at urban sustainability transition labs (USTL) and utilized $\log$ models to assess USTL outputs and outcomes, both site specific and city-wide. Studies have also looked into whole food systems (Institute of Medicine and National Research Council, 2015), but local initiatives in relation to food were not taken into account. The development of assessment tools for measuring and mapping social food innovations and their contribution to sustainability and systemic change still remains incomplete (Aubin et al., 2013; see also Chapters $4 \& 7$, this volume). 


\section{Valette et al.}

Multiple evaluation methodologies rely on standardized, expert-led, and quantitative data collection and analysis tools to ensure comparability, reproducibility, and objectivity. For instance, such methods are chosen in fields like agriculture, health, and water management (Peterson, 2006) under the assumption that these provide sufficient data and advice for unbiased and scientifically informed decision-making (Leach et al., 2010). On the other hand, Naudet et al. (2012) argue that quantitative and financial evaluations neglect crucial elements, underlining their inability to establish the cause and effect relationship that allows one to assess development policies or any kind of project.

Aubin et al. (2013) conducted a critical review of sustainability evaluation methods and their applicability in the food system, consisting of common methods ranging from Life Cycle Assessment (LCA); economic methods such as cost-benefit analysis (CBA); retrospective assessment of food uses and resources; physical and synthetic indicators of environmental pressures; nutritional and epidemiological approaches; methods to assess obstacles to, and motivations for, sustainable consumption; composite social and ethical indicators; and multi-criteria and participatory assessment tools. Their main critiques are that prevailing methods are too global (input-output analysis); too local (LCA); too single-dimensional (physical and synthetic indicators); too static (LCA, economic methods, physical, and synthetic indicators); too predictable and narrow in methodology (LCA); too imprecise (LCA); require data that is difficult to acquire (input-output); are vulnerable to errors (input-output); or too focused on macro-nutrients (food availability) and consumer motivation (assessment of sustainable consumption); or do not take informal economic trade into consideration (input-output). This latter concern is especially relevant in developing and emerging countries. At the same time, Aubin et al. (2013) deny qualitative or context-specific elements or, for instance in the case of cost-benefit calculations, undervalue potential future dynamics (Howarth \& Norgaard, 2013) in favour of the focus on current value flows (Portney \& Weyant, 1999). Lastly, focusing on effect measurement methods, they neglect to scrutinize causal relationships (Mayne, 2011).

\section{The various dimensions of sustainability}

Sustainable development, as introduced in the Brundtland report (World Commission on Environment and Development, 1987), has significantly influenced the demands on, and the design of, assessment tools that must deal with contextual (site-specific conditions) and temporal issues (impacts occur at various, often lengthy, times after the intervention), as well as multidisciplinarity (Temple et al., 2018). Based on these considerations, new and more qualitative approaches to sustainability assessment have been proposed to help urban food system governance. Some methods for identifying relevant sustainability indicators range from expert-led choices 
to more participatory processes that help communities identify their own indicators (Fraser et al., 2005; Abi-Nader et al., 2009; see also Chapters $1 \&$ 12, this volume). For example, Landert et al. (2017) developed a participatory process to operationalize the Guidelines for Sustainability Assessment of Food and Agriculture Systems (SAFA) developed by the UN Food and Agriculture Organization (FAO). The multi-criteria assessment method uses 97 indicators evaluating 51 of the SAFA sub-themes. The choice of the indicators is based on a comprehensive approach of a sustainable food system and is based on policies and measures related to processes within the urban food system.

Very recently, Carlsson et al. (2017) have proposed a participatory methodology based on the Framework for Strategic Sustainable Development (FSSD) through a modified Delphi Inquiry Process to identify key indicators for tracking progress towards the success of the food system at a local level (see also Chapter 7, this volume). Both in Landert et al. (2017) and Carlsson et al. (2017), the methodology implementation has been made possible thanks to the availability of data. Two improvements on these approaches are worth noting. First, data availability might not be guaranteed in developing countries. Second, in both cases, methodologies aim to assess and improve the whole food system and its sustainability more than to drive and improve local innovations.

Finally, while several research teams have explored the assessment of sustainability innovation impacts on the food system, they often limit the assessment to one or two dimensions of sustainability: environmental issues (with LCA tools) and/or nutrition (through consumption surveys) (see Chapter 10, this volume). The interactions between sustainability dimensions have rarely been taken into account. In order to better address this gap, some assessment methodologies use participatory mapping to identify and explore impact pathways of innovations (Douthwaite et al., 2007a; Proietti et al., 2015). URBAL follows this path.

\section{It's also about politics}

Evaluation also has a political dimension. Since sustainability transition experiments are embedded within structures and power relations, selfcritical reflexivity within an evaluation is required (Avelino \& Rotmans, 2009). Adding the concept of complex adaptive systems (see Chapter 4, this volume), one must acknowledge that projects and programmes are embedded in political, institutional, social, and economic systems, which evaluators can use to understand how these systemic affiliations and structures hinder or foster causal chains.

Even though a more holistic perspective covering impacts on sustainability is desired (Joly et al., 2015), most approaches are nevertheless onedimensional. More recent ones try to balance these methodological obstacles by analysing, for instance, networks, political and institutional arrangements, 


\section{Valette et al.}

as well as the use and production of knowledge to help policymakers in the quest to negotiate between different, often conflicting or competing options and pathways to social improvement (Bozeman \& Sarewitz, 2011; BlayPalmer et al., 2018). Some studies have addressed these methodological drawbacks. For instance, a recent study by Sanyé-Mengual et al. (2018) aimed to approach the field of urban agriculture research assessment and investigated the linkages between sustainability dimensions in urban food production through a participatory evaluation.

Rather than picking any random methodology, it is crucial to stand back and reflect on the needs and interests of stakeholders, the questions they want to answer, and the available resources (Fawcett et al., 2003; Neubert, 2010; also see Chapter 1, this volume). Both internal and external factors must be considered, such as public relations for marketing and funding acquisition purposes (Berg et al., 2009), 'accountability requirements', the 'existence of procedural routines for social inquiry', as well as the 'nature of the sought knowledge', are pivotal in the decision process towards an epistemologically fitting assessment toolset (Dhondt et al., 2016, p. 22) or internal purposes like project management and learning (Berg et al., 2009). Therefore, the efficacy of the demanded methodology depends on customizability, in order to account for the diversity of numerous forces in play (Dhondt et al., 2016). Specifically for use in participatory settings, the methodology should be inclusionary and facilitate capacity building and learning, as well as be comprehensible and easy to apply (SpringerHeinze et al., 2003).

\section{The URBAL methodology: change-based and participatory theory}

Based on these theoretical and methodological contexts, the participatory methodology that is being developed uses two main interwoven considerations and approaches.

\section{Impact pathways}

The aim of the URBAL methodology is to help disentangle the goals and strategies that lead an innovation to sustainability, not necessarily to measure its impact. That is why we chose to work with impact pathway mapping. While the identification of impacts can give clues about the effects and implications of a programme, project, or other initiative, it cannot answer the question of how and why an impact has occurred. Evaluation must be capable of disentangling the goals of a programme and the strategies in place to reach them (McLaughlin \& Jordan, 2015). Pawson et al. (2005) emphasize the importance of outcome-generating mechanisms, causality, and the comprehension of both in their 'generative model of causality': 'to infer a causal outcome $(\mathrm{O})$ between two events (X and $\mathrm{Y})$, one needs to understand the underlying 
mechanisms $(\mathrm{M})$ that connect them and the context $(\mathrm{C})$ in which the relationship occurs' (Pawson et al., 2005, p. 22).

In the process of planning, organizations that perform social innovations often define specific goals they want to reach in response to the social construction of a problem. These goals are ideally tied to immediate targets, yet are long-term-oriented, clearly formulated, and measurable. More generally, innovators are able to draw the proposed path towards achievement of their stated goals. Doing so, organizations articulate external and internal economic, political, environmental, and social drivers that can alter the trajectory towards their chosen goals. They construct (implicitly or explicitly) several pathways and choose the one with the highest estimated efficiency (OECD, 2013). This logic can be defined as a theory of change, which proposes an explanation about how the actions and activities of a programme, intervention, or project are intended to contribute to planned effects and the reasons and mechanisms that link the operation (Mayne, 2011).

Impact Pathways Analysis (IPA) is a popular approach to investigate theories of change in the planning and evaluation process, using logic models to visualize elements and links for an intervention. IPA can provide a useful tool as it is dedicated to the questions of why and how a given intervention has led to an impact on whom, and which specific conditions were in play (GIZ, 2012; Quiédeville et al., 2017), by mapping and discussing these components (Dhondt et al., 2016).

IPA serves a descriptive function, that is, grasping the activities, circulation, transformation, and utilization of knowledge (Quiédeville et al., 2015) and other elements. Furthermore, it aims to provide an understanding of cause and effect relationships that have led to change (Reade, 2008) on the micro, meso, and macro levels (GIZ, 2012). The 'pathways approach' recognizes that these complex interactions can sometimes be selfreinforcing, strengthening dominant narratives and trajectories favoured by powerful actors, and crowding out alternatives favoured by marginal groups. Impact pathways analysis helps to challenge and scrutinize change processes and their dynamics (Reade, 2008). Particularly challenging can be documenting the evidence for undesired impacts, long-term impacts, and diffuse impacts, which do not address a specifically demarcated target group. While IPA has been applied in diverse contexts, it has mainly been carried out for research and development accountability programme evaluation to communicate with external funders and stakeholders. Other methodologies, ${ }^{1}$ including ours, are more practitioner-oriented, where impact pathways are rather a management and strategy tool, that is, for internal use.

\section{Participatory-based}

Evaluative studies have often been conducted by researchers and other scientific experts. However, the approach to research on rather than with 
stakeholder groups, can lead to insufficient and biased conclusions that do not mirror the lived experiences of the impacted stakeholders. Many researchers therefore suggest using participatory approaches in order to address these shortcomings (Hummelbrunner, 2007; Meter, 2007; Berg et al., 2009). Multi-stakeholder planning has been described as especially crucial in complex agro-food systems (De Zeeuw \& Dubbeling, 2015); the same can be applied to the evaluation perspective.

Participatory approaches are commonly chosen in impact pathways analysis since they allow a balance between the researchers' needs for specific information and the ability of participants to contribute their original experience. Cousins and Earl (1992) define participatory evaluation as 'applied social research that involves a partnership between trained evaluation personnel and practice-based decision makers, organization members with programme responsibility; or people with a vital interest in the program' (p. 399). In this case, the assessment takes place in a collaboration between stakeholders and experts, which also enables cross-comparison between statements (Berg et al., 2009). Hummelbrunner (2007) argues that this constellation in itself forms a system, the 'evaluation system', in which 'clients' and 'evaluators' influence each other's world views by intervening and reacting.

Participatory evaluation can have different operational benefits: it increases the usability and relevance of results into the everyday practices of participants (Cousins \& Earl, 1992) through the appropriation of the evaluation process (Quiédeville et al., 2017), and the opportunity to raise locally relevant questions (Zukoski \& Bosserman, 2017). Scholars also value participatory evaluation as very effective because of the possibility to adjust ongoing projects and programmes during execution, as well as to immediately recover from unexpected disruptions (Rodríguez-Campos, 2017). Participatory evaluation is not just the programme, project, or product, but also a process that enables dialectic discussions, which should lead to organizational learning (Suárez-Herrera et al., 2009), allow participants to express their opinions, have their voice and perspectives incorporated into the initiative (Marra, 2015), and provide systematic information to support learning and decision-making (Douthwaite et al., 2007b). This has been shown to support the integration of new ideas and constructs into existing mental maps and cognitive structures. The application of participatory evaluation and the stimulation of learning knowledge creation can also foster change (Plottu \& Plottu, 2009; Marra, 2015). Scholars argue that capacity building is yet another important potential of participatory evaluation (EkirapaKiracho et al., 2017).

A crucial part of the participatory evaluation methodology is the involvement of a wide and diverse range of key stakeholders (McLaughlin \& Jordan, 2015; Zukoski \& Bosserman, 2017), although the extent of involvement and the diversity of stakeholders can vary throughout the 
process at different stages (Rodríguez-Campos, 2017). Certainly, this diversity can render the evaluation difficult and make consensus impossible to achieve. Nevertheless, in the least case, it can generate a platform where conflicting perspectives can be laid open and discussed. Discussion and juxtaposition of the reasons and processes of change are the main purposes.

\section{A three-stage process}

Based on these statements, URBAL proposes to build and test a tool that can help different actors identify the potential and risks for different sustainability dimensions for urban food system innovations. Building from assumptions of participatory engagement, such as participatory budgeting (Cabannes, 2004) or participatory certification (Nelson et al., 2010), we will focus on policymakers and practitioners. The goal is to build a cognitive map or logical frame that makes explicit the impact of innovations on sustainability. These maps will identify the actual changes produced by the innovation on sustainability, the ways they are induced by the activities performed by the innovation, and the ways they interrelate, from short-term changes (outputs) to medium-term (outcomes) and to longterm changes (usually referred to as impacts). The chosen approach will therefore assess not only the intended and unintended impacts on all sustainability dimensions, but also the pathways that led to these changes. These pathways that help identify a theory of change for each innovation are not necessarily linear constructs: the interrelation, convergence, potential divergency between the various changes and pathways towards the different dimensions of sustainability, also build a systemic theory of change, emphasizing positive and negative feedback loops, unforeseen changes, and unforeseen contradictions between pathways, which we believe are particularly relevant to address the issue of the sustainable food systems.

The URBAL project aims to offer innovators, funders, and policymakers useful and clear information about the functionality and relevance of innovations. It aims at providing policymakers the tools to allocate funding and implement appropriate support mechanisms to foster sustainable change and prevent adverse societal effects. It also aims at providing innovators the tools to better assess their activities and to reframe their goals if they identify gaps and strengths. As such it will be of a participatory or collaborative nature (see also Chapter 8, this volume).

A key goal is to address all dimensions of food system sustainability. The sustainability framework developed by Bricas (2017) is at the core of URBAL's research approach so that we include economic, environmental, socio-cultural, food security, and nutrition and governance considerations as central to our research. 


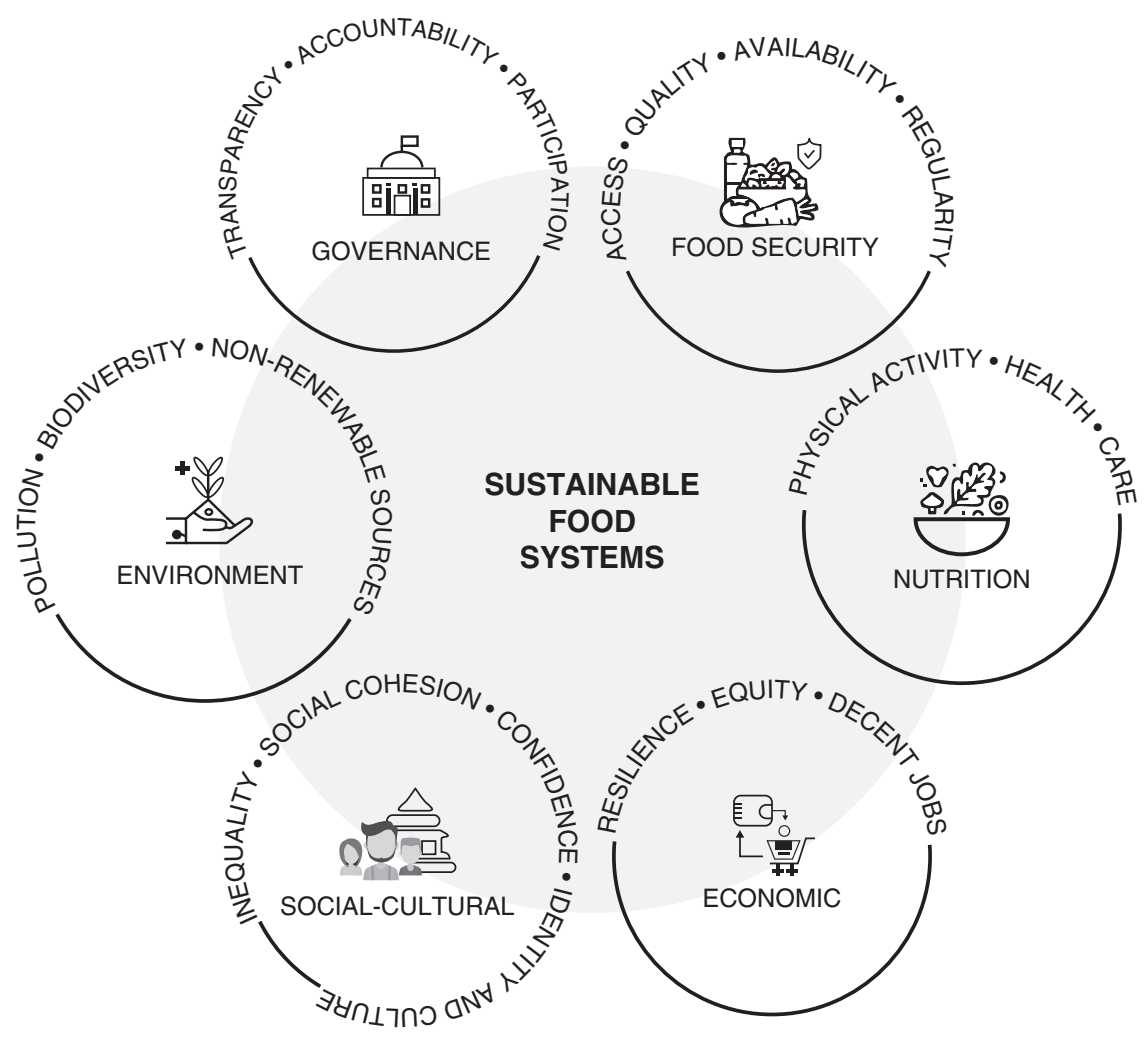

Figure 2.1 The dimensions of sustainable food systems.

Source: Adapted from Bricas, 2017.

As Figure 2.1 shows, the sustainability dimensions encompass five main areas:

- Social dimensions include social cohesion, inequality, confidence in the food system, as well as identity and culture;

- Economic dimensions include decent jobs, equity, and resilience considerations;

- Food security and nutrition dimensions are closely linked and include physical activity, health care as well as food access, availability, regularity, and quality;

- Environmental dimensions include pollution, biodiversity, and nonrenewable resources;

- Governance dimensions include participation, transparency, and accountability. 


\section{A stakeholder-oriented methodology}

As a general roadmap, we suggest a three-stage collaborative process (Figure 2.2), that will help document the innovation impacts. To consider long-established innovations as emerging ones (in which case it would be difficult to identify actual impacts due to the nascent nature of the innovation), and to dispel the fuzzy image that comes with the term 'impacts', one of the first methodological choices was to use the term 'change' and 'result' instead of 'impact'. In this context, outputs are the products or services generated by the innovation. Outputs can lead to direct observable changes and can be adopted and adapted by other actors in the same or other contexts. This is what we call 'Results' - short-term, medium-term or long-term changes linked to the innovation and its context, which are both influenced by and influence contextual factors.

The central question is ' $\mathrm{How}$ have ideas and/or practices changed because of the innovation?' In order to address this question, Step 1 will be dedicated to the collection of background information through interviews that will help to raise awareness about the innovation, document the context, and understand the motivation of the practitioners for the innovation. The main outputs of Step 1 will be (1) a chronogram, which displays visually the most relevant events in the genesis and the development of the innovation; (2) an actor network map that diagrams the system of actors and their mutual relationships; (3) a case description including the local and global context for the innovation; and finally (4) an impact pathway map that describes what strategies the project's stakeholders have used and what activities they have performed to bring about necessary actions to achieve the project vision, including unexpected short-term and long-term changes, as well as takes into account positive and negative feedback loops, as previously said.

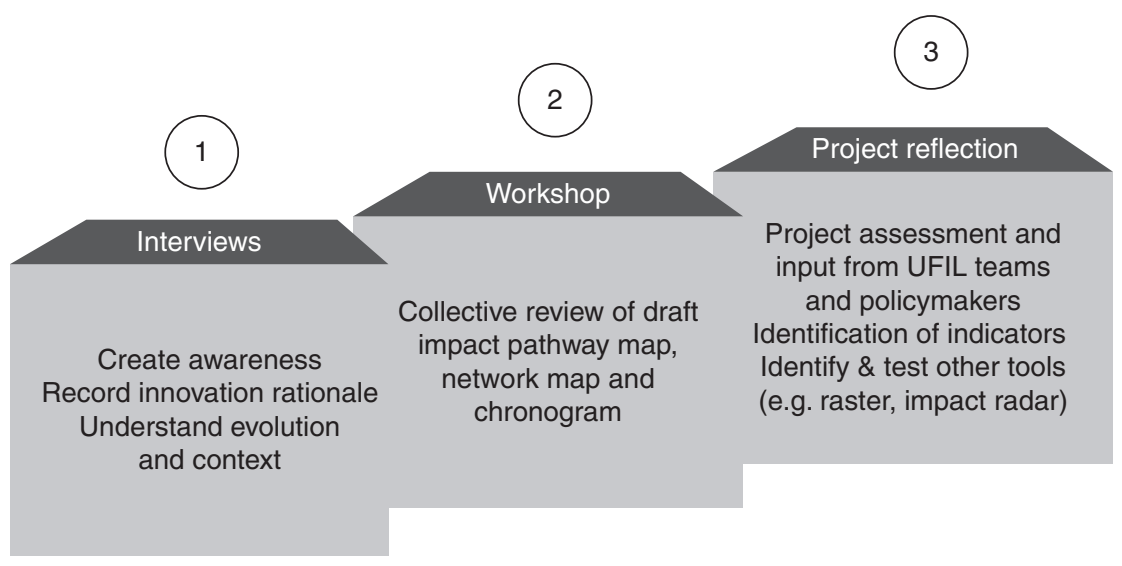

Figure 2.2 The three stages of the URBAL methodology. 
This cognitive map is based on an Outcome Logic Model, which will be explained in the next section.

In Step 2, a workshop is organized involving stakeholders (practitioners, partners, users) to review the Impact Pathway map developed in Step 1 and discuss comments and improvements to the various pathways leading from the innovation to related changes. This step is dedicated to discussing and reflecting on the innovation's theory of change and evolution, which the innovators defined in Step 1. This step is crucial for the confirming or challenging the impact pathways identified in Step 1 through interviews and a literature review. It is also crucial for defining, discussing, and potentially eliminating causal linkages between each pathway step, and gaining awareness about the process and elements of the innovation (specifically policymakers, who can benefit from this knowledge in order to increase the efficiency of their decision-making). The selection of the workshop participants will depend on the sustainability dimensions and on the questions that will be addressed in depth in the workshop. As such, this selection strongly relies on the outputs of Step 1.

Step 3 is a meeting or a workshop to reflect on the results and the project as a whole with innovators, stakeholders, policymakers, and/or funders. This final step may also be used to identify indicators for benchmarking and actually measuring changes and impacts.

Stakeholders are the core actors in impact pathway mapping. It is advisable to involve 'wise practitioners', that is, people who are well immersed in the relevant area of interest but can also offer broader, more abstract contexts. Furthermore, food system innovations connect a multitude of different actors and stakeholders that should be categorized to provide a wide-ranging overview (Meter, 2007; see also Chapter 4, this volume) making the actor mapping in Step 1 so crucial.

The Impress method suggests the separation of actors into three categories (major actors, influential actors, and impacted actors) according to the role they play in the innovation process (Barret et al., 2018). This idea is used and adapted to URBAL, which proposes the following four categories:

1. Innovation holders: ideally founding members of the innovation.

2. Policymakers: representatives from municipal or regional governments with policymaking capacity, ideally with previous knowledge about the concerns in the sphere of the UFIL. These actors could come from economic development, health, tourism, planning, or a number of other government departments.

3. Stakeholder representatives: according to the relevance for each innovation along the food supply chain - producer, transformer, distributor, consumer, waste management, governance.

4. Sustainability experts: knowledgeable about different sustainability dimensions, not necessarily involved in innovation or in the URBAL team. 
Both the practitioners who emerged in the field of interest, and the sustainability experts who have a more abstract view on linkages and results, can provide a well-balanced analysis. In reality, representatives might have multiple roles and responsibilities and can offer a range of diverse insights. Drawing a stakeholder affiliation map for each UFIL will be a valuable tool to identify the density of linkages and diversity of roles that are combined within one UFIL.

\section{A logic model to help map impact pathways}

The logic model used in our impact pathway mapping involves a representation of how sustainable innovation holders identify or construct one or more social concerns that they aim to address by formalizing an operational project (Figure 2.3). According to this project, inputs (financial, human, material, capital, and other resources that enable the intervention to generate a product or service) are defined and elaborated from the innovation context. Through innovation activities defined by the operational mission, actions transform inputs into outputs. As previously said, for URBAL, especially during the workshops, short-term, medium-term, and long-term 'results' are used instead of 'outcomes' and 'impacts' to account for the differences brought about by the innovation. Outcomes can be regarded as direct short-term effects on immediate stakeholders, while impacts refer to medium- to longterm effects that go beyond the scope of the direct actors and users. From a pragmatic point of view, this understanding sets the URBAL methodology apart from other methodology that focuses on academic purposes. Referring to 'outcomes', 'impacts' could lead to confusion as different disciplines and practitioner groups may have conflicting views on this term. 'Changes' and 'results' are simpler terms that facilitate work in a participative way. For example, it may not be appropriate to use the term 'impact', because most of the social innovations we will work on have been founded recently. To us, both 'changes' and 'results' are appropriate to compensate for the relative difficulty of 'impacts' as well as the uncertainty related to their identification.

The diagram presented here has been shaped at the very beginning to the URBAL project, before any live-test with an innovation. Since then, we have been able to perform this test twice and have significantly modified the methodology, from the logic model to the very practical aspects of its implementation. One example is the end of the distinction between outputs and results in favour of a more general distinction between short-term, mediumterm, and long-term changes.

\section{Twelve Urban Food Innovation Labs}

The methodology will be tested on a total of 12 UFILs (Table 2.1) are engaged during the three years of the project in eight cities, including Montpellier (2), Milan (3), Hanoi (2), Rabat, Brasilia, Baltimore, Cape Town, and Berlin. 


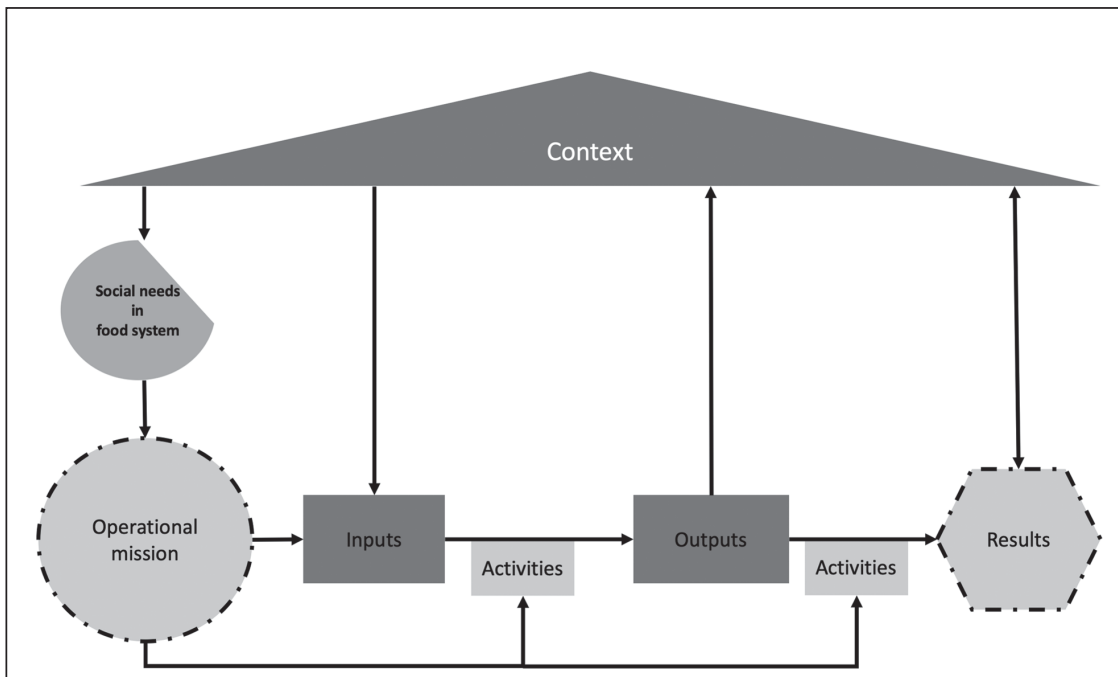

Figure 2.3 A frame for impact pathway mapping.

Source: URBAL.

- Context(s) of urban-driven social innovation (SI) for sustainable food systems consists of internal and external opportunities and obstacles. The context influences, and is influenced by, the SI.

- Example: Economic, social, environmental, political, and cultural factors (at a local and at larger scale, depending on the relevance for each UFIL).

- Sustainability needs in the food system refers to demands in relation to food that are not yet being met. Such needs can actually exist or be only perceived by SI holders.

- Example: Food poverty in an urban neighbourhood. While needs tend to be social in nature, they can be driven by other needs, for example, to improve soil quality.

- Operational mission describes the vision and strategies that SI holders set for their intervention to address a need. This mission is the guiding principle of the intervention and is the basis for input acquisition and activities to metabolize inputs into outputs. It roughly resembles the theory of change.

- Example: Reducing food poverty through voluntary social work and support by the municipality to empower people to gain ownership of their own food supply.

- Inputs are the physical and non-physical factors needed to achieve the SI's objective. Inputs are retrieved from both the internal and external contexts.

- Example: Volunteers, social innovation grants, and support from civil servants.

- Activities defines actions that are undertaken to use and transform inputs into outputs or generate results.

○ Example: Board meetings, job creation, teaching, sales, and applications.

- Outputs are all products and services directly generated by an SI through the transformation of inputs.

- Examples: Mobile apps, cooking workshops, and food store concepts.

- Results or changes refer to changes that can be linked to an SI. These results are relative, that is, there is a noteworthy difference between the status quo and the previous condition. A result is the consequence of the application or use of an SI's output by the target group and other stakeholders. A result can also occur indirectly and unplanned, and alter conditions positively or negatively.

- Example: Knowledge about the closest location to acquire healthy food. 
UFILs were selected using a multifaceted typology based on the following four key questions: (a) Where are the changes expected: on consumer practices; on value-chains; and/or on governance of urban food policies? (b) What is the type of sustainability innovation, including the satisfaction of human needs, changes to social relations, increasing levels of socio-political capability, and asset building at individual and/or community levels (Kirwan et al., 2013)? (c) Who originates the innovation: civil society; the private sector; and/or local public authorities? (d) How many dimensions of sustainability are addressed among environmental, socio-cultural, economic, food security and nutrition, and governance? Only those innovations whose constructed vision involves at least two sustainability dimensions have been selected for participation.

Other criteria include: legitimacy and precedence of participative approaches; institutional context including whether food policies exist and if they do whether they are local and if they are led as top-down, bottomup, or a mixture of initiatives; development and cultural contexts; stage of the innovation, from initial planning through emergent to fully developed and mature innovations; expected outcomes of the innovations, including scaling up, out, and deep (Riddell \& Moore, 2015); and, status of the innovation as novel, adapted from elsewhere, or imitated.

Table 2.1 Innovation origins and expected changes for the 12 URBAL Urban Food Innovation Labs (UFILs)

\begin{tabular}{|c|c|c|c|}
\hline & $\begin{array}{l}\text { Changes in } \\
\text { consumer practices }\end{array}$ & $\begin{array}{l}\text { Changes in value- } \\
\text { chain organization }\end{array}$ & $\begin{array}{l}\text { Changes in urban } \\
\text { food policy } \\
\text { governance }\end{array}$ \\
\hline $\begin{array}{l}\text { Innovation from } \\
\text { civil society }\end{array}$ & $\begin{array}{l}\text { Collaborative } \\
\text { consumer } \\
\text { supermarket, } \\
\text { Montpellier }\end{array}$ & $\begin{array}{l}\text { Participatory } \\
\text { guarantee system } \\
\text { Rabat }\end{array}$ & $\begin{array}{l}\text { Food Aid } \\
\text { Milan }\end{array}$ \\
\hline $\begin{array}{l}\text { Innovation from } \\
\text { private sector }\end{array}$ & $\begin{array}{l}\text { Promotion of native } \\
\text { species from the } \\
\text { Cerrado biome in } \\
\text { the gastronomy } \\
\text { Brasilia } \\
\text { Internet usage in } \\
\text { Food provisioning } \\
\text { and information } \\
\text { Hanoi }\end{array}$ & $\begin{array}{l}\text { Aquaponics } \\
\text { as innovative } \\
\text { supply chain } \\
\text { Berlin }\end{array}$ & $\begin{array}{l}\text { Community Food } \\
\text { Committees for } \\
\text { urban health and } \\
\text { nutrition } \\
\text { Cape Town }\end{array}$ \\
\hline $\begin{array}{l}\text { Innovation from } \\
\text { public authorities }\end{array}$ & $\begin{array}{l}\text { Support to } \\
\text { innovations in } \\
\text { school canteens, } \\
\text { Montpellier }\end{array}$ & $\begin{array}{l}\text { Long-distance } \\
\text { contracts between city } \\
\text { and hinterland } \\
\text { Hanoi } \\
\text { Public procurement } \\
\text { for school canteens, } \\
\text { Milan }\end{array}$ & $\begin{array}{l}\text { Food Policy } \\
\text { Advisor Network, } \\
\text { Baltimore } \\
\text { Distretto Agricolo } \\
\text { Milanese } \\
\text { Milan }\end{array}$ \\
\hline
\end{tabular}




\section{Valette et al.}

The URBAL method will be adapted to the needs and context of each UFIL, thanks to a step-by-step improvement of the method (Figure 2.3). Live tests of the methodology will be done in three waves with feedback analysis from participants after each wave, which will help evolve the methodology. As at April 2019, two tests have already been performed, ten more are still to be organized. The final version of the methodology will be available at the conclusion of this phase of the project, projected for the end of 2020.

In each of these cities where innovations have been chosen, the main partners of the projects have strong links with scientific teams. Several of these cities are actively part of national or international networks on urban food systems. This will help to better connect the URBAL project to other cities and to disseminate the results of the project.

\section{Conclusion}

Testing this methodology on various innovations in diverse contexts will allow the researchers to present an analysis of the actual effects, the potentialities, the risks, and the limits of urban innovations on the sustainability of food systems (including outside the urban perimeter). In such a way, this research will contribute to the analysis of how city regions can be part of solutions and contribute to more sustainable food systems even if they are, to a large extent, responsible for the existing pressures on planetary boundaries.

The research outcomes are expected to demonstrate conditions when urban-driven initiatives, including urban food policies, may provide beneficial medium-term or long-term changes (i.e. impacts), helping urban areas to collaborate with rural partners in their regions in the transition towards more sustainable food systems. It is also expected that the lessons learned will in turn pose new challenges. One purpose of the research project is to contribute to reversing the image of cities as a main source of unsustainability as cities are frequently and deservedly associated with negative environmental impacts, unequal availability, and accessibility to balanced and affordable nutritious food for city dwellers. URBAL will explore urban spaces as sources of innovative solutions to sustainability issues. This, in turn, can be linked to other initiatives including the Milan Urban Food Policy Pact and strategies being developed to link the Sustainable Development Goals (SDGs) to urban food system practice (Calori et al., 2017; Blay-Palmer et al., 2018).

The approach also makes an important contribution at the intersection of impact pathways mapping literature and participatory methods by developing a more precise set of terms to describe the innovation process. This enables a more robust and complex analysis and responds to the needs and questions of the various stakeholders actually or potentially engaged in the innovation (Fawcett et al., 2003; Douthwaite et al., 2007a; Neubert, 2010; see also Chapter 1, this volume). In turn, it is expected that the specific innovations in the UFILs will allow the project to address 
questions about forces both external to the innovation process, including procedural routines, or the innovation aims, including marketing and funding goals (Dhondt et al., 2016, p. 22), or internal factors such as project management and learning and can provide specific information to foster learning, consensus building, and decision-making (Douthwaite et al., 2007b; Berg et al., 2009; Suárez-Herrera et al., 2009). That URBAL is inclusive and flexible, allows it to meet these goals as well as build capacity and agency for organizational stakeholders (Springer-Heinze et al., 2003; Marra, 2015; see also Chapter 4, this volume). As it is developed in tandem with practitioners and reflects their everyday practice, it is more usable, flexible, and relevant (Rodríguez-Campos, 2017; Zukoski \& Bosserman, 2017).

Beyond research interest, this method will also help practitioners and innovation stakeholders to capture the very effect of their actions and give them the resources to enable them to be more reflexive and strategic about their innovation pathway, for their organization, as well as for their communication with policymakers and investors. The impact pathways will extract details and interconnections about the process and innovation and will make impacts/results more transparent and more easily understood. This method can be a low-tech and low-cost tool for policymakers, innovators, and funders to understand more about existing and proposed urban food innovations.

\section{Acknowledgements}

URBAL ( $\mathrm{N}^{\circ} 1507-200 \mathrm{AF}$; $\mathrm{N}^{\circ} \mathrm{FC} 2015-2440, \mathrm{~N}^{\circ}$ FDNC Engt 00063479) is supported under the 'Thought for Food' Initiative of Agropolis Fondation (through the 'Investissements d'avenir' programme with reference number ANR-10-LABX-0001-01'), Fondazione Cariplo and Daniel \& Nina Carasso Foundation. The Social Sciences and Humanities Research Council of Canada supports the FLEdGE Partnership, a Canadian partner. We also recognize the valuable contribution of our community and academic partners, as well as the URBAL WP leaders and the Scientific Advisory Committee.

\section{Note}

1 Specifically in the 2010s, the development of the distinct impact pathways approach has skyrocketed. Many interesting approaches, mainly from agricultural research, contributed to the improvement and adaptation of concepts to a diverse range of interest fields. Researchers have proposed and developed different methodologies that assess, model, analyse, and evaluate the processes that (most likely) lead to a specific impact, such as PIPA, ImpresS, IMPRESA, and Syalinnov. 


\section{References}

Abi-Nader, J., Ayson, A., Harris, K., Herrera, H., Eddins, D., Habib, D., \& Villanueva, L. (2009) Whole measures for community food systems: Values-based planning and evaluation. Burlington, VT, Center for Whole Communities.

Aubin, J., Donnars, C., Supkova, M., Dorin, B., Gaillard, G., Garcia, F., ... Rojot, C. (2013) A critical panorama of methods used to assess food sustainability. In: Esnouf, C., Russel, M., \& Bricas, N. (Eds.) Food system sustainability: Insights from duALIne. Cambridge, Cambridge University Press, pp. 198-232.

Avelino, F. \& Rotmans, J. (2009) Power in transition: An interdisciplinary framework to study power in relation to structural change. European Journal of Social Theory. 12(4), pp. 543-569. Available at: https://doi.org/10.1177/1368431009349830.

Barret, D., Blundo Canto, G., Dabat, M.-H., Devaux-Spatarakis, A., Faure, G., Hainzelin, E., ... Triomphe, B. (2018) ImpresS methodological guide. Methodological guide to ex post impact of agricultural research in developing countries. Montpellier, France, Cirad. Available at: https://doi.org/10.19182/agritrop/00006.

Bennett, C.J. \& Howlett, M. (1992) The lessons of learning: Reconciling theories of policy learning and policy change. Policy Sciences. 25(3), pp. 275-294.

Berg, C., Causeman, B., Guenther, D., Hochgesang, T., Müller, R., Neubert, S., \& Quack, M. (2009) Landkarte Wirkungsanalyseverfahren (Arbeitskreis 'Evaluation von Entwicklungspolitik in der DeGEval'). Available at: https:// www.researchgate.net/profile/Susanne_Neubert2/publication/238786352_ Herausgeber_Arbeitskreis_Evaluation_von_Entwicklungspolitik_in_der_ DeGEval/links/5594d80608ae5d8f392f82e4/Herausgeber-ArbeitskreisEvaluation-von-Entwicklungspolitik-in-der-DeGEval.pdf.

Blay-Palmer, A., Sonnino, R., \& Custot, J. (2016) A food politics of the possible? Growing sustainable food systems through networks of knowledge. Agriculture and Human Values. 33(1), pp. 27-43.

Blay-Palmer, A., Santini, G., Dubbeling, M., Renting, H., Taguchi, M., \& Giordano, T. (2018) Validating the city region food system approach: Enacting inclusive, transformational city region food systems. Sustainability. 10(5), p. 1680.

Born, B. \& Purcell, M. (2006) Avoiding the local trap: Scale and food systems in planning research. Journal of Planning Education and Research. 26(2), pp. 195-207.

Bozeman, B. \& Sarewitz, D. (2011) Public value mapping and science policy evaluation. Minerva. 49(1), pp. 1-23. Available at: https://doi.org/10.1007/ s11024-011-9161-7.

Brand, C. (2015) Alimentation et métropolisation: repenser le territoire à l'aune d'une problématique vitale oubliée. Thèse de doctorat en géographie, université Grenoble Alpes, Laboratoire PACTE, Grenoble.

Brand, C., Bricas, N., Conaré, D., Daviron, B., Debru, J., Michel, L., \& Soulard, C.-T. (Eds.) (2017) Construire des politiques alimentaires urbaines. Paris, Editions Quae.

Bricas, N. (2017) Les enjeux de l'urbanisation pour la durabilité des systèmes alimentaires. In: Brand, C. et al. (Eds.) Construire des politiques alimentaires urbaines. Concepts et démarches. Paris, Editions Quae, pp. 19-38.

Cabannes, Y. (2004) Participatory budgeting: A significant contribution to participatory democracy. Environment and Urbanization. 16(1), pp. 27-46.

Callon, M., Barthe, Y., \& Lascoumes, P. (2001). Agir dans un monde incertain. Essai sur la démocratie technique, Seuil. 
Calori, A., Dansero, E., Pettenati, G., \& Toldo, A. (2017) Urban food planning in Italian cities: A comparative analysis of the cases of Milan and Turin. Agroecology and Sustainable Food Systems. 41(8), pp. 1026-1046.

Carlsson, L., Callaghan, E., Morley, A., \& Broman, G. (2017) Food system sustainability across scales: A proposed local-to-global approach to community planning and assessment. Sustainability. 9(6), p. 1061.

Clancy, K. (1994) Commentary social justice and sustainable agriculture: Moving beyond theory. Agriculture and Human Values. 11(4), pp. 77-83.

Cousins, J.B. \& Earl, L.M. (1992) The case for participatory evaluation. Educational Evaluation and Policy Analysis. 14(4), pp. 397-418.

Desrochers, P. \& Shimizu, H. (2008) Yes, we have no bananas: A critique of the 'food miles' perspective. Fairfax, VA, Mercatus Center, George Mason University. Available at: https://www.mercatus.org/system/files/Yes_We_Have_No_Bananas_ _A_Critique_of_the_Food_Mile_Perspective.pdf.

De Zeeuw, H. \& Dubbeling, M. (2015) Process and tools for multistakeholder planning of urban agro-food systems. In: de Zeeuw, H. \& Drechsel, P. (Eds.) Cities and Agriculture - Developing Resilient Urban Food Systems. London, Earthscan Food and Agriculture, Routledge, pp. 56-87.

Dhondt, S., Van de Ven, H., Ziauberyte, R., Van der Torre, W., Cressey, P., Kaderabkova, A., ... Terstriep, J. (2016) Ex-ante impact assessment \& value network analysis for SI. Gelsenkirchen, Institute for Work and Technology. Available at: https://repository.tudelft.nl/view/tno/uuid\%3A843a0c44-4e02-4213-9ff5-b03b0ff081d6.

Douthwaite, B., Alvarez, B.S., Cook, S., Davies, R., George, P., Howell, J., Mackay, R., \& Rubiano, J. (2007b) Participatory impact pathways analysis: A practical application program theory in research for development. The Canadian Journal of Program Evaluation. 22(2), pp. 127-159.

Douthwaite, B., Schulz, S., Olanrewaju, A.S., \& Ellis-Jones, J. (2007a) Impact pathway evaluation of an integrated Striga hermonthica control project in northern Nigeria. Agricultural Systems. 92(1-3), pp. 201-222. Available at: https:// doi.org/10.1016/j.agsy.2006.03.007.

Ekirapa-Kiracho, E., Ghosh, U., Brahmachari, R., \& Paina, L. (2017) Engaging stakeholders: Lessons from the use of participatory tools for improving maternal and child care health services. Health Research Policy and Systems. 15(Suppl 2), pp. 17-28. Available at: https://doi.org/10.1186/s12961-017-0271-z.

Fawcett, S.B., Boothroyd, R., Schultz, J.A., Francisco, V.T., Carson, V., \& Bremby, R. (2003) Building capacity for participatory evaluation within community initiatives. Journal of Prevention \& Intervention in the Community. 26(2), pp. 21-36. Available at: https://doi.org/10.1300/J005v26n02_03.

Fraser, D.G.E., Dougill, A.J., Mabee, W.E., Reed, M., \& McAlpine, P. (2005) Bottom up and top down: analysis of participatory process for sustainability indicator identification as a pathway to community empowerment and sustainable environmental management. Journal of Environmental Management. 78, pp. 114-127.

Freidberg, S. (2003) Cleaning up down south: Supermarkets, ethical trade and African horticulture. Social and Cultural Geography. 4(1), pp. 27-43.

Friedmann, H. (2007) Scaling up: Bringing public institutions and food service corporations into the project for a local, sustainable food system in Ontario. Agriculture and Human Values. 24, pp. 389-398.

GIZ (Ed.) (2012) Wirkungsanalyse und Wirkungsmessung in Gesundheitsvorhaben der deutschen Entwicklungszusammenarbeit: Verbesserungsbedarf vor dem 
Hintergrund internationaler Erfahrungen und Entwicklungen. Deutsche Gesellschaft für Internationale Zusammenarbeit (GIZ) GmbH. Available at: https://repository.publisso.de/resource/frl:5202307-1/data.

Hall, P.A. (1993) Policy paradigms, social learning, and the state: The case of economic policymaking in Britain. Comparative Politics. 25(3), pp. 275-296.

Howarth, R.B. \& Norgaard R.B. (2013) Intergenerational Transfers and the Social Discount Rate. Environmental and Resource Economics. 3(4), pp. 337-358.

Hummelbrunner, R. (2007) Systemic evaluation in the field of regional development. In: Williams, B. \& Imam, I. (Eds.) Systems concepts in evaluation: An expert anthology. Point Reyes, CA, EdgePress of Inverness for the American Evaluation Association, pp. 161-180.

Institute of Medicine and National Research Council. (2015) A framework for assessing effects of the food system. Washington, DC, The National Academies Press. https://doi.org/10.17226/18846

Jobert, B. \& Muller, P. (1987) L'état en action. Politiques publiques et corporatismes, Paris, PUF.

Joly, P.B., Gaunand, A., Colinet, L., Larédo, P., Lemarié, S., \& Matt, M. (2015) ASIRPA: A comprehensive theory-based approach to assessing the societal impacts of a research organization. Research Evaluation. 24(4), pp. 440-453.

Katz, D. (2010). The myth of food miles. In: Fraser Forum (April), pp. 21-23. Fraser Institute. Available at: https:/www.fraserinstitute.org/sites/default/files/from-thearchive-myth-of-food-miles_0.pdf.

Kirwan, J., Ilbery, B., Maye, D., \& Carey, J. (2013) Grassroots social innovations and food localization: An investigation of the local food programme in England. Global Environmental Change. 23(5), pp. 830-837. Available at: https://doi.org/ 10.1016/j.gloenvcha.2012.12.004.

Laidlaw, J. (2015) Food security: A core component of a leading city's transformation agenda. Melbourne, Australia, UN Global Compact Cities Programme.

Landert, J., Schader, C., Moschitz, H., \& Stolze, M. (2017) A holistic sustainability assessment method for urban food system governance. Sustainability. 9(4), p. 490. Available at: https://doi.org/10.3390/su9040490.

Lang, T. (1999) The complexities of globalization: The UK as a case study of tensions within the food system and the challenge to food policy. Agriculture and Human Values. 16, pp. 169-185.

Leach, M., Scoones, I., \& Stirling, A. (2010) Dynamic sustainabilities: Technology, environment, social justice. Washington, DC, Earthscan.

Luederitz, C., Schäpke, N., Wiek, A., Lang, D.J., Bergmann, M., Bos, J.J., ... Westley, F.R. (2017) Learning through evaluation: A tentative evaluative scheme for sustainability transition experiments. Journal of Cleaner Production. 169, pp. 61-76. Available at: https://doi.org/10.1002/9781119171386.ch3.

Mah, C.L. \& Thang, H. (2013) Cultivating food connections: The Toronto food strategy and municipal deliberation on food. International Planning Studies. 18(1), pp. 96-110.

Marra, M. (2015) Cooperating for a more egalitarian society: Complexity theory to evaluate gender equity. Evaluation. 21(1), pp. 32-46. Available at: https://doi.org/ 10.1177/1356389014564856.

Mason, J.B. (1985) Données requises pour l'évaluation des effets nutritionnels des projets de développement agricole et rural: document destiné aux planificateurs des projets. Rome, FAO. 
Mayne, J. (2011) Contribution analysis: Addressing cause and effect. In: Forss, K., Marra, M., \& Schwartz, R. (Eds.) Evaluating the complex: Attribution, contribution, and beyond. Piscataway, NJ, Transaction Press.

McLaughlin, J.A. \& Jordan, G.B. (2015) Using logic models. In: Newcomer, K.E., Hatry, H.P., \& Wholey, J.S. (Eds.) Handbook of practical program evaluation. Hoboken, NJ, John Wiley \& Sons, pp. 62-87.

Meter, K.A. (2007) Evaluating farm and food systems in the US. In: Williams, B. \& Imam, I. (Eds.) Systems concepts in evaluation: An expert anthology. Point Reyes, CA, EdgePress of Inverness for the American Evaluation Association, pp. 141-159.

Moragues-Faus, A. \& Marsden, T. (2017) The political ecology of food: Carving 'spaces of possibility' in a new research agenda. Journal of Rural Studies. 55, pp. 275-288.

Naudet, J., Delarue, J., \& Bernard, T. (2012) Impact evaluations: A tool for accountability? Lessons from experience in AFD. Revue d'économie du développement. 20(4), pp. 27-48. Available at: doi:10.3917/edd.264.0027.

Nelson, E., Tovar, L.G., Rindermann, R.S., \& Cruz, M.Á.G. (2010) Participatory organic certification in Mexico: An alternative approach to maintaining the integrity of the organic label. Agriculture and Human Values. 27(2), pp. 227-237.

Neubert, S. (2010) Description and examples of MAPP method for impact assessment of programmes and projects. German Development Institute. Available at: http:// www.ngo-ideas.net/mediaCache/MAPP/MAPP-Description.pdf.

OECD (2013) Development results: An overview of results measurement and management. Available at: https://www.oecd.org/dac/peer-reviews/DevelopmentResults-Note.pdf.

Patton, M.Q. (2012) Essentials of utilization-focused evaluation. Thousand Oaks, CA, Sage Publications.

Pawson, R., Greenhalgh, T., Harvey, G., \& Walshe, K. (2005) Realist review: A new method of systematic review designed for complex policy interventions. Journal of Health Services Research \& Policy. 10(1), pp. 21-34. Available at: https://doi. org/10.1258/1355819054308530.

Peterson, M. (2006) The precautionary principle is incoherent. Risk Analysis. 26(3), pp. 595-601. Available at: https://doi.org/10.1111/j.1539-6924.2006.00781.x.

Plottu, B. \& Plottu, É. (2009) Contraintes et vertus de l'évaluation participative. Revue française de gestion. 2(192), pp. 31-58.

Popov, E.V., Veretennikova, A.Y., \& Omonov, Z.K. (2017) A social innovation impact assessment matrix. Digest Finance. 22(4), pp. 365-378. https://doi.org/ 10.24891/re.15.9.1752

Portney, P.R. \& Weyant, J.P. (1999) Discounting and intergenerational equity. Baltimore, MD, Taylor \& Francis.

Proietti, C., Wittine, D., Alvarez, S., Parker, M., Schulte-Geldermann, E., Stoian, D., \& Thiele, G. (2015) Co-constructing impact pathways with stakeholders for results-based management. CGIAR Research Program on Roots, Tubers and Banana, Brief $n^{\circ} 1$.

Quiédeville, S., Barjolle, D., Mouret, J.C., \& Stolze, M. (2017) Ex-post evaluation of the impacts of the science-based research and innovation program: A new method applied in the case of farmers' transition to organic production in the Camargue. Journal of Innovation Economics. 22(1), p. 145. Available at: https:// doi.org/10.3917/jie.022.0145. 
Quiédeville, S., Barjolle, D., Stolze, M., \& Mouret, J.C. (2015) Impacts of sciencebased research and innovation program: The case of farmers' transition to organic production in Camargue. Conference paper at: Impacts of agricultural research: an approach of societal values. Paris, 3-4 November.

Reade, N. (2008) Konzept für alltagstaugliche Wirkungsevaluierungen in Anlehnung an Rigorous Impact Evaluations: Erprobung der Durchführung im Rahmen von GTZ Unabhängigen Evaluierungen. Available at: https://docplayer.org/55849Konzept-fuer-alltagstaugliche-wirkungsevaluierungen-in-anlehnung-an-rigorousimpact-evaluations.html.

Reardon, T. (2015) The hidden middle: The quiet revolution in the midstream of agrifood value chains in developing countries. Oxford Review of Economic Policy. 31(1), pp. 45-63.

Reynolds, B. (2009) Feeding a world city: The London food strategy. International Planning Studies. 14(4), pp. 417-424.

Riddell, D. \& Moore, M-L. (2015) Scaling out, Scaling up, Scaling deep: Advancing systemic social innovation and the learning processes to support it. Paper prepared for the J.W. McConnell Family Foundation and Tamarack Institute, Toronto and Waterloo, ON.

Robineau, O. (2015) Toward a systemic analysis of city-agriculture interactions in west Africa: A geography of arrangements between actors. Land Use Policy. 49, pp. 322-331.

Rocha, C. \& Lessa, I. (2009) Urban governance for food security: The alternative food system in Belo Horizonte, Brazil. International Planning Studies. 14(4), pp. 389-400.

Rodríguez-Campos, L. (2017) Essentials of collaborative evaluation. In: Fetterman, D.M., Rodríguez-Campos, L., \& Zukoski, A.P. (Eds.) Collaborative, participatory, and empowerment evaluation: Stakeholder involvement approaches. New York, Guilford Publications.

Rose, R. (1993) Lesson-drawing in public policy: A guide to learning across time and space. Chatham, NJ, Chatham House Publishers.

Sanyé-Mengual, E., Orsini, F., \& Gianquinto, G. (2018) Revisiting the sustainability concept of urban food production from a stakeholders' perspective. Sustainability. 10(7), 2175. Available at: https://doi.org/10.3390/su10072175.

Singh, R.K., Murty, H.R., Gupta, S.K., \& Dikshit, A.K. (2012) An overview of sustainability assessment methodologies. Ecological Indicators. 15(1), pp. 281-299.

Slocum, R., Cadieux, K., \& Blumberg, R. (2016) Solidarity, space, and race: Toward geographies of agrifood justice. Justice spatiale - Spatial Justice. 9(January).

Springer-Heinze, A., Hartwich, F., Henderson, J.S., Horton, D., \& Minde, I. (2003) Impact pathway analysis: An approach to strengthening the impact orientation of agricultural research. Agricultural Systems. 78(2), pp. 267-285. Available at: https://doi.org/10.1016/S0308-521X(03)00129-X.

Suárez-Herrera, J.C., Springett, J., \& Kagan, C. (2009) Critical connections between participatory evaluation, organizational learning and intentional change in pluralistic organizations. Evaluation. 15(3), pp. 321-342. Available at: https://doi. org/10.1177/1356389009105884.

Temple, L., Barret, D., Blundo Canto, G., Dabat, M.H., Devaux-Spatarakis, A., Faure, G., \& Triomphe, B. (2018) Assessing impacts of agricultural research for development: A systemic model focusing on outcomes. Research Evaluation. 27(2), pp. 157-170. Available at: https://doi.org/10.1093/reseval/rvy005. 
UNEP (2011) Decoupling natural resource use and environmental impacts from economic growth. A report of the working group on decoupling to the international resource panel. United Nations Environment Programme, Nairobi, Kenya.

Viljoen, A. \& Wiskerke, J.S. (2012) Sustainable food planning: Evolving theory and practice. Wageningen, Wageningen Academic Publishers.

Wertheim-Heck, S., Spaargaren, G., \& Vellema, S. (2014) Food safety in everyday life: Shopping for vegetables in a rural city in Vietnam. Journal of Rural Studies. 35, pp. 37-48.

Wiek, A., Kay, B., \& Forrest, N. (2017) Worth the trouble?! An evaluative scheme for urban sustainability transition labs (USTLs) and an application to the USTL in Phoenix, Arizona. In: De Niki, F., Loorbach, D., Castán Broto, V., \& Coenen, L. (Eds.) Urban sustainability transitions. New York, Taylor \& Francis, pp. 227-256.

World Commission on Environment and Development (1987) Our common future. Oxford, Oxford University Press.

Zukoski, A.P. \& Bosserman, K. (2017) Essentials of participatory evaluation. In: Fetterman, D.M., Rodríguez-Campos, L., \& Zukoski, A.P. (Eds.) Collaborative, participatory, and empowerment evaluation: Stakeholder involvement approaches. New York, Guilford Publications. 